\title{
KAJIAN TENTANG HUBUNGAN PERTUMBUHAN VEGETATIF DENGAN PRODUKSI TANAMAN TOMAT (Lycopersicum esculentum, Mill )
}

\author{
SURTINAH \\ Staf Pengajar Fakultas Peratnian Universitas Lancang Kuning \\ Jurusan Agronomi \\ Jl. D. I. Panjaitan Km. 8 Rumbai Telp.(0761)52439
}

\begin{abstract}
ABSTRAK
Tujuan penelitian ini adalah untuk mendapatkan parameter yang memiliki hubungan paling erat antara parameter pertumbuhan tanaman tomat dengan berat buah tomat. Penelitian ini merupakan penelitian kepustakaan yang membuat suatu kajian tentang hasil penelitian yang sudah dilakukan, sehingga data yang diperoleh adalah data sekunder. Analisa data menggunakan regresi polinomial yang akan menggambarkan seberapa besar keeratan hubungan antara tinggi tanaman dengan berat buah tanaman tomat per tanaman, hubungan antara junlah cabang dengan berat tanaman tomat per tanaman, dan hubungan antara Diameter batang dengan berat buah tomat per tanaman. Hasil analisis regresi memerlihatkan keeratan hubungan antara pertumbuhan vegetatif tanaman tomat yaitu tinggi tanaman, jumlah cabang, dan diameter batang terhadap berat buah tomat per tanaman. Tinggi tanaman, Jumlah cabang, dan Diameter batang memiliki keeratan hubungan terhadap produksi buah tomat, oleh karena itu untuk penelitian selanjutnya parameter tersebut perlu diuji seberapa besar keeratan hubungan antara pertumbuhan vegetatif dengan pertumbuhan generatifnya.
\end{abstract}

Kata Kunci : Hubungan, Vegetatif, Produksi, Tomat, regresi polinomial.

\section{PENDAHULUAN}

Tomat merupakan tanaman sayuran buah yang sangat dibutuhkan oleh manusia untuk memenuhi kebutuhan hidupnya. Hal ini disebabkan oleh karena kandungan gizi buah tomat yang terdiri dari vitamin dan mineral sangat berguna untuk mempertahankan kesehatan dan mencegah penyakit.

$$
\text { Prospek pengembangan }
$$
tanaman tomat sangat menjanjikan, karena beberapa hal yang disebutkan di atas, sehingga banyak penelitianpenelitian yang dilakukan dengan menggunakan tomat sebagai tanaman indikator. Namun penelitian yang dilakukan masih bersifat uji coba beberapa macam pupuk yang baru dirilis dan konstribusinya dalam meningkatkan produksi saja.

Fakultas

Pertanian

Universitas Lancang Kuning juga banyak melakukan penelitian seperti yang disebutkan di atas, namun apa yang terjadi dibalik proses produksi tersebut tidak diungkapkan secara jelas. Pada umumnya Dosen dan Mahasiswa melakukan penelitian hanya untuk mendapatkan produksi yang maksimal, dan hal itu sudah tercapai berdasarkan tujuan penelitiannya. Tetapi hal - hal yang mempengaruhi produksi tidak diungkapkan secara jelas, sehingga menimbulkan suatu pertanyaan 
apakah faktor yang terlupakan tersebut memberikan konstribusi terhadap produksi ? inilah yang perlu mendapat jawaban.

Produksi suatu tanaman tidak terlepas dari pertumbuhan vegetatifnya, bagaimana kondisi pertumbuhan vegetatifnya dapat memberikan konstribusi yang positif terhadap pertumbuhan generatifnya ?, itu perlu dijabarkan melalui suatu kajian tersendiri, walaupun sebenarnya hal ini dapat dilakukan sekaligus, namun keterbatasan ktrampilan mahasiswa dalam menganalisa hasil penelitian menyebabkan hal ini menjadi terabaikan.

Parameter pertumbuhan tanaman memberikan gambaran bagaimana produksi tanaman tersebut, namun apakah semua parameter yang diukur di dalam suatu penelitian memberikan gambaran tentang produksinya ?, inilah yang menjadi permasalahan. Karena tidak semua parameter pertumbuhan vegetatif yang di ukur menunjukkan hubungan yang erat terhadap produksi.

Penelitian - penelitian tentang tanaman tomat yang tujuannya untuk mendapatkan produksi maksimum, selalu mengukur tinggi tanaman tomat, diameter batang, dan Jumlah cabang, namun apakah ketiga parameter tersebut memiliki hubungan yang erat dengan produksi ? jawabannya belum pasti karena belum diuji.

Dari hasil penelitian yang dilakukan oleh Surtinah ( 2001 ) mendapatkan bahwa Pupuk gandasil B berpengaruh terhadap tinggi tanaman tomat, jumlah cabang utama, dan diameter batang utama. Hasil penelitian ditampilkan dalam tabel 1. di bawah ini.

Tabel 1. Data Hasil Penelitian Rata-rata Tinggi Tanaman, Jumlah cabang, dan Diameter batang tanaman tomat.

\begin{tabular}{|c|c|c|c|}
\hline $\begin{array}{c}\text { Perlakuan } \\
\text { Gandasil B }\end{array}$ & Tinggi tanaman & Jumlah cabang & Diameter batang \\
\hline $0 \mathrm{~g}$ & $8.45 \mathrm{a}$ & $2.00 \mathrm{a}$ & $1.14 \mathrm{a}$ \\
\hline $1.125 \mathrm{~g}$ & $9.00 \mathrm{c}$ & $3.25 \mathrm{~b}$ & $1.25 \mathrm{~b}$ \\
\hline $2.25 \mathrm{~g}$ & $9.82 \mathrm{e}$ & $3.625 \mathrm{~b}$ & $1.50 \mathrm{c}$ \\
\hline $3.375 \mathrm{~g}$ & $9.61 \mathrm{~d}$ & $3.375 \mathrm{~b}$ & $1.48 \mathrm{c}$ \\
\hline $4.50 \mathrm{~g}$ & $8.70 \mathrm{~b}$ & $2.250 \mathrm{a}$ & $1.18 \mathrm{ab}$ \\
\hline
\end{tabular}

Hasil uji beda rata - rata perlakuan dilakukan dengan menggunakan uji lanjut DNMRT pada taraf uji $5 \%$. Disimpulkan bahwa dengan meningkatnya pemberian gandasil B maka pertumbuhan tinggi tanaman, jumlah cabang, dan diameter batang mengalami peningkatan, dan pada dosis tertentu ketiga parameter tersebut mengalami penurunan pertumbuhan.
Peningkatan pertumbuhan disebabkan karena unsur - unsur yang terkandung dalam gandasil B mampu melaksanakan perannya dalam pembelahan sel, unsur $\mathrm{K}$ dan $\mathrm{Mg}$ berperan dalam memperlancar proses fotosintesis, sehingga asimilasi yang dihasilkannya dapat dimanfaatkan untuk proses pertumbuhan ( Salisbury dan Ross, 1992 ). 
Pada penelitian yang dilakukan oleh Surip ( 2004 ) melaporkan bahwa kombinasi perlakuan antara pupuk Urean dan Gandasil B berpengaruh nyata terhadap tinggi tanaman, diameter batang dan jumlah cabang. Simpulan dari penelitian ini adalah bahwa pupuk urea dengan kandungan $\mathrm{N}$ nya, dan Gandasil $\mathrm{B}$ dengan kandungan unsur hara makro dan mikro dapat mempercepar pertumbuhan vegetatif tanaman tomat, hal ini diperkuat oleh Lingga ( 2000 ) bahwa unsur N yang dikandung oleh kedua pupuk tersebut berfungsi dalam menyususn klorofil dan pertumbuhan vegetatif terutama daun, sehingga membantu proses fotosintesis, selain itu juga untuk membentuk asam nukleat.

Pada tahun yang sama Sariyanto ( 2004 ) melaporkan hasil penelitiannya sebagai berikut, tinggi tanaman tomat dan jumlah cabang tanaman dipengaruhi oleh perlakuan Atonik dan Dosis pupuk kandang. Simpulan dari penelitian ini menyebutkan bahwa pupuk kandang berpengaruh terhadap tinggi tanaman dan jumlah cabang disebabkan karena pupuk kandang dapat memperbaiki sifat fisik tanah, sehingga perakaran tanaman menjadi lebih baik pertumbuhannya.

Gardner et al. ( 1991 ) menyatakan bahwa bagian tanaman yang memberikan konstribusi paling banyak terhadap pertumbuhan dan perkembangan tanaman adalah daun, dan sebagian hasil asimilasi tetap tertinggal dalam jaringan untuk pemeliharaan sel, bila translokasi lambat, dapat diubah menjadi tepung atau bentuk cadangan makanan lainnya. Sisanya diekspor ke daerah pemanfaatan vegetatif yang terdiri dari fungsi-fungsi pertumbuhan, pemeliharaan dan cadangan makanan.

Susi ( 2006 ) melaporkan bahwa kombinasi perlakuan antara pupuk organik spesial dengan Liquinox start menghasilkan tinggi tanaman tomat dan jumlah cabang per tanaman yang berbeda tidak nyata.

Literatur yang menjelaskan tentang distribusi hasil asimilasi selalu menyebutkan bahwa daerah sumber yang menjadi pemasok utama adalah daun karena daun yang memliki permukaan yang lebih luas untuk menyerap intensitas cahaya dan digunakan untuk fotosintesis. Pada kajian ini akan di lihat apakah tinggi tanaman, jumlah cabang dan diameter batang punya peranan terhadap produksi ?

Tujuan Penelitian adalah untuk mendapatkan parameter pertumbuhan vegetatif yang memiliki hubungan yang erat dengan produksi tomat

\section{METODE ENELITIAN}

\section{Jenis Penelitian}

Penelitian ini merupakan

penelitian kepustakaan yang

berdasarkan hasil penelitian yang pernah dilakukan tentang tanaman tomat.

\section{Sumber Data}

Sumber data di peroleh dari penelitian Surtinah ( 2001 ), Surip ( 2004 ), Sariyanto ( 2004 ), dan Susi ( 2006 ).

\section{Teknik Analisa Data}


Aanalisa data menggunakan regresi polynomial, dimana akan kita dapatkan keeratan hubungan antara pertumbuhan vegetatif dan produksi tomat melaui koefisien regresi $\left(\mathrm{R}^{2}\right)$, dengan model regresi sebagai berikut$$
Y=b o+b_{1} x+b_{2} x^{2}+\varepsilon
$$$$
\text { ( Sumber : Gomez dan Gomez }
$$ 1995 )}

Data yang akan dianalisa adalah hubungan antara data tinggi tanaman dan produksi tomat, hubungan antara jumlah cabang dengan produksi tomat, dan hubungan antara diameter batang dengan produksi tomat.

\section{HASIL DAN PEMBAHASAN}

Analisis regresi yang digunakan untuk mencari hubungan antara pertumbuhan vegetatif tanaman tomat dengan produksi tomat diperlihatkan pada Gambar 1 . sampai dengan Gambar 10.
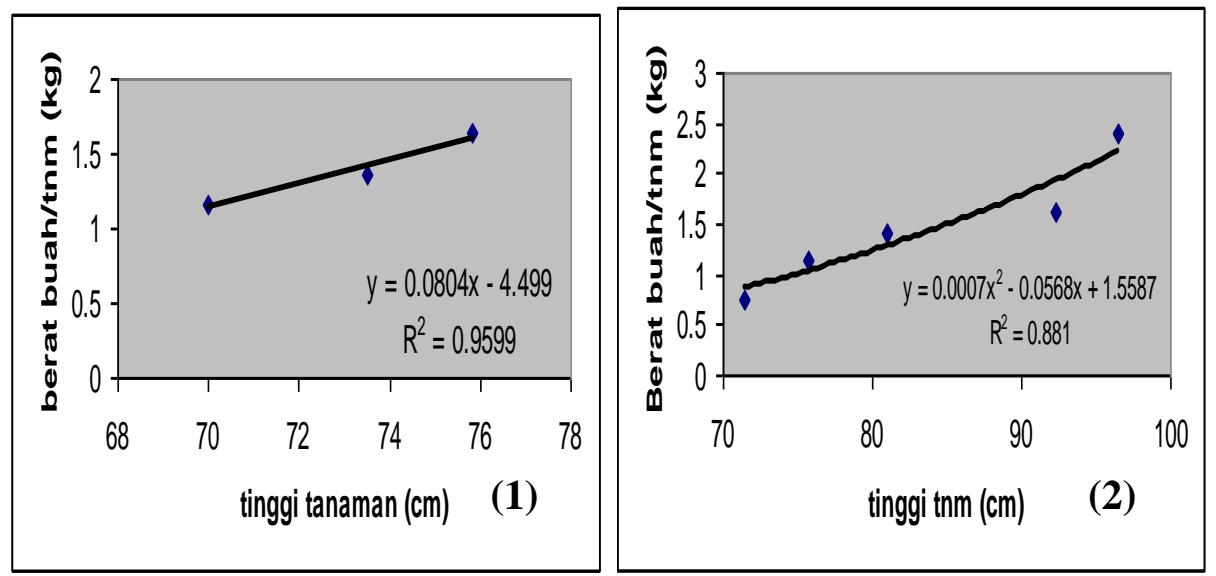

Gambar 1. Kurva hubungan antara tinggi tanaman tomat dengan berat buah tomat pada penelitian Surip ( 2004)

Gambar 2. Kurva hubungan antara tinggi tanaman tomat dengan berat buah tomat pada penelitian Surtinah (2001). dan $\begin{gathered}\text { Hubungan tinggi } \\ \text { produksi }\end{gathered}$ buah $\begin{array}{r}\text { tanaman } \\ \text { tomat }\end{array}$ diperlihatkan pada Gambar 1., Gambar 2., Gambar 3, dan Gambar 4. Hasil penelitian yang dilakukan oleh Surip ( 2004 ) memperlihatkan hubungan dalam bentuk garis linear melalui persamaan gar $\mathrm{Y}=-4.499+$ $0.0804 \mathrm{x}$, dan koefesien regresi $\mathrm{R}^{2}=$ $95.99 \%$, yang berarti bahwa $95.99 \%$ peningkatan berat buah tomat per tanaman dapat dijelaskan oleh peningkatan tinggi tanaman, atau dengan kata lain bahwa semakin tinggi tanaman tomat maka berat buah semakin meningkat. Dugaan lain fenomena ini adalah semakin tinggi tanaman semakin banyak cabangnya dan semakin banyak bunga yang dihasilkan dari cabangcabang tersebut, namun demikian semuanya tidak terlepas dari perlakuan yang diberikan pada tanaman, misalnya pemupukan dan pengendalian hama. 

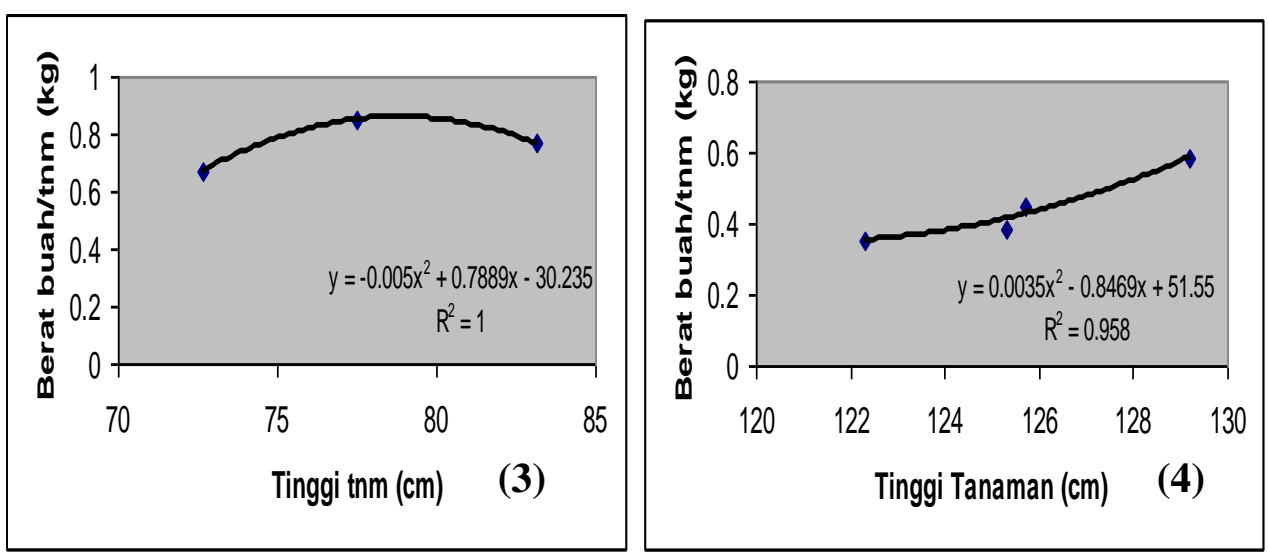

Gambar 3. Kurva hubungan antara tinggi tanaman tomat dengan berat buah tomat pada penelitian Sariyanto ( 2004 ).

Gambar 4. Kurva hubungan antara tinggi tanaman tomat dengan berat buah tomat pada penelitian Susi ( 2006 )

Demikian juga hubungan tinggi tanaman dengan berat buah per tanaman pada penelitian yang dilakukan oleh Surtinah ( 2001 ) digambarkan melalui persamaan garis $\mathrm{Y}=1.5587-0.0568 \mathrm{x}+$ $0.0007 \mathrm{x}^{2}$ dengan nilai $\mathrm{R}^{2}=88 \%$. Pada gambar tersebut juga terlihat peningkatan berat buah per tanaman akibat peningkatan tinggi tanaman.

Pada Gambar 3. Hasil penelitian yang dilakukan oleh Sariyanto ( 2004 ), memperlihatkan hubungan antara tinggi tanaman dengan berat buat tomat per tanaman melalui persamaan garis $\mathrm{Y}=$ $30.235+0.7889 x-0.005 x^{2}$ dengan nilai $R^{2}=1$. Dari gambar tersebut dapat dilihat bahwa semakin tinggi tanaman tomat maka berat buah tomat per tanaman juga semakin meningkat., namun pada titik tertentu terjadi penurunan berat buah.

Gambar 4. memperlihatkan hubungan yang erat antara tinggi tanaman dengan berat buah tomat per tanaman, hal ini diperlihatkan melalui persamaan garis $\mathrm{Y}=51.55$ $0.8469 \mathrm{x}+0.0035 \mathrm{x}^{2}$ dengan nilai $\mathrm{R}^{2}$ $=95 \%$ ( Susi, 2006 ) yang artinya bahwa $95 \%$ kenaikan berat buah tomat per tanaman dapat dijelaskan oleh kenaikan tinggi tanaman.

Gambar 1. sampai dengan Gambar 4. di depan semua memperlihatkan hubungan yang erat antara tinggi tanaman tomat dengan berat buah tomat per tanaman. Sehingga dari keempat penelitian yang sudah dilakukan, parameter tinggi tanaman bisa dijadikan sebagai acuan untuk memprediksi berat buah tomat per tanaman.

Parameter Jumlah cabang pada Gambar 5. memperlihatkan hubungan yang erat dengan berat buah tanaman tomat. Berat buah meningkat, namun pada titik tertentu mengalami penurunan dengan dengan bertambahnya jumlah cabang. Kurva dibentuk berdasarkan persamaan garis $\mathrm{Y}=-113.05+$ $67.072 \mathrm{x}-9.0519 \mathrm{x}^{2}$, dengan nilai $\mathrm{R}^{2}$ $=1$. Pada penelitian ini diduga bahwa tidak semua cabang merupakan cabang produktif, atau dengan bertambahnya cabang maka buah semakin banyak, namun bobot buah menjadi berkurang karena asimilat harus di distribusikan untuk seluruh sink yang ada ( Sariyanto, 2004 ). 
Hasil penelitian yang dilakukan Susi ( 2006 ) dapat diperlihatkan pada Gambar 6. Persamaan garis regresi yaitu $\mathrm{Y}=$ $16.606-2.2203 \mathrm{x}+0.0757 \mathrm{x}^{2}$, dengan nilai $\mathrm{R}^{2}=96 \%$, yang menggambarkan keeratan hubungan antara jumlah cabang dengan berat buah tomat per tanaman. Semakin banyak cabang tomat maka berat buah per tanaman semakin tinggi.
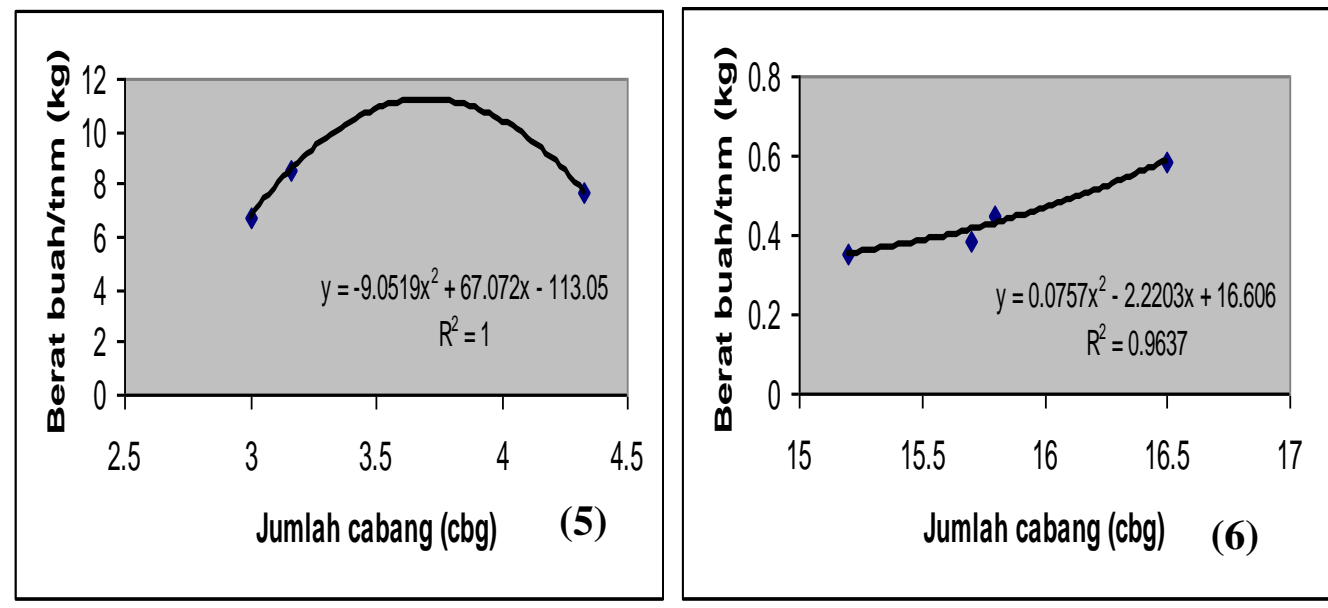

Gambar 5. Kurva hubungan antara Jumlah cabang tanaman tomat dengan berat buah tomat per tanaman ( Sariyanto, 2004 )

Gambar 6. Kurva hubungan antara jumlah cabang tanaman tomat dengan berat buah tomat per tanaman ( Susi, 2006 )

Hasil penelitian Surip ( 2004 ) dapat dilihat pada Gambar 7. Dimana keeratan hubungan antara jumlah cabang dengan berat buah tomat per tanaman hanya $67 \%$ saja dengan persamaan garis $\mathrm{Y}=0.5606$ $+0.1869 \mathrm{x}$, yang artinya $67 \%$ berat buah tomat dapat dijelaskan oleh jumlah cabang.

Penelitian yang dilakukan Surtinah ( 2001 ) tertuang dalam Gambar 8, yang menggambarkan bahwa jumlah cabang erat hubungannya dengan berat buah tomat per tanaman. Hal ini diperlihatkan oleh nilai $\mathrm{R}^{2}=87.71$ $\%$.

Pada penelitian ini peningkatan jumlah cabang dua kali lipat akan menambah berat buah tomat per tanaman semakin tinggi. Sehingga dapat disimpulkan bahwa semakin banyak cabang maka berat buah tomat per tanaman semakin tinggi.. Dugaan untuk parameter ini bahwa semakin banyak jumlah cabang maka kesempatan untuk berproduksi juga semakin besar, dimana kita ketahui bahwa bunga tomat keluar pada cabang - cabang yang terbentuk tersebut. Cabang cabang yang produktif ini akan menghasilkan bunga apabila fasilitas yang dibutuhkan tnaman tomat tersebut terpenuhi melalui perlakuanperlakuan yang benar-benar mendukung untuk peningkatan produksi.

Gambar 5. sampai dengan Gambar 8. memperlihatkan keeratan hubungan antara jumlah cabang dengan berat buah tomat per tanaman. Sehingga dari keempat penelitian tersebut dapat disimpulkan bahwa jumlah cbang memberikan konstribusi yang positif terhadap 
berat buah tomat per tanaman. Yang perlu diingat bahwa jumlah cabang yang dimaksud adalah jumlah cabang yang produktif, tidak

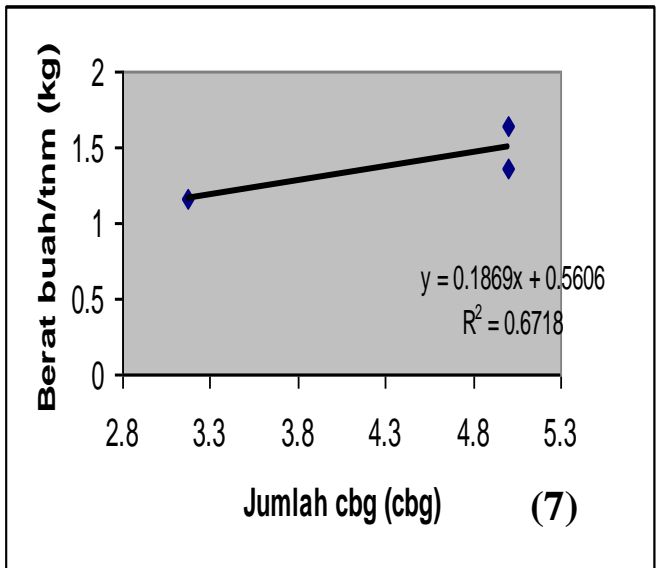

termasuk tunas liar, karena tunas ini merupakan cabang yang perlu dipangkas.

Gambar 7. Kurva hubungan antara Jumlah cabang tanaman tomat dengan berta buah tomat per tanaman ( Surip, 2004 )

Gambar 8. Kurva hubungan antara jumlah cabang tanaman tomat dengan berat buah tomat ( Surtinah, 2001)

Gambar 9. dan Gambar 10. akan memperlihatkan hubungan antara diameter batang tomat dengan berat buah tomat per tanaman. Penelitian yang dilakukan oleh Surip ( 2004 ) menggambarkan diameter batang tomat yang semakin besar, akan meningkatkan berat buah tomat per tanaman. Keertan hubungan itu digambarkan oleh nilai $\mathrm{R}^{2}=97 \%$ dengan persamaan garis regresi $\mathrm{Y}=$ $0.7972+0.2032 \mathrm{x}$.

$$
\text { Pada Gambar }
$$

10. memperlihatkan hasil penelitian yang dilakukan Surtinah ( 2001 ) menggambarkan keeratan hubungan yang sama dengan penelitian Surip ( 2004 ). Pada penelitian tersebut hubungan antara diameter batang dengan berat buah tomat per tanaman ditunjukkan oleh nilai $\mathrm{R}^{2}=79.41 \%$, melalui persamaan garis $\mathrm{Y}=$ $10.741+15.362 \mathrm{x}-4.5549 \mathrm{x}^{2}$.

Dari Gambar 9. dan Gambar 10. tersebut di atas jelas terlihat bahwa diameter batang juga memberikan konstribusi yang baik dalam meningkatkan berat buah tomat per tanaman. Semakin besar batang tomat maka akan memberikan berat buah tomat per tanaman semakin tinggi, walaupun dapat dilihat bahwa peningkatan itu mungkin hanya sampai dititik tertentu saja, karena ada kecenderungan akan menurun dengan bertambah besarnya diameter batang tomat.

Gambar - gambar yang ditampilkan memberi arti bahwa pengukuran terhadap tinggi tanaman, Junlah cabang, dan Diameter batang tanaman tomat perlu dilakukan, karena ternyata ke tiga parameter tersebut memberikan hubungan yang erat melalui uji regresi terhadap peningkatan berat buah tomat per tanaman, dan untuk penelitian selanjutnya perlu di uji seberapa besar hubungan antara pertumbuhan vegetatif tanaman tomat dan peningkatan produksi buah tomat per tanaman. 

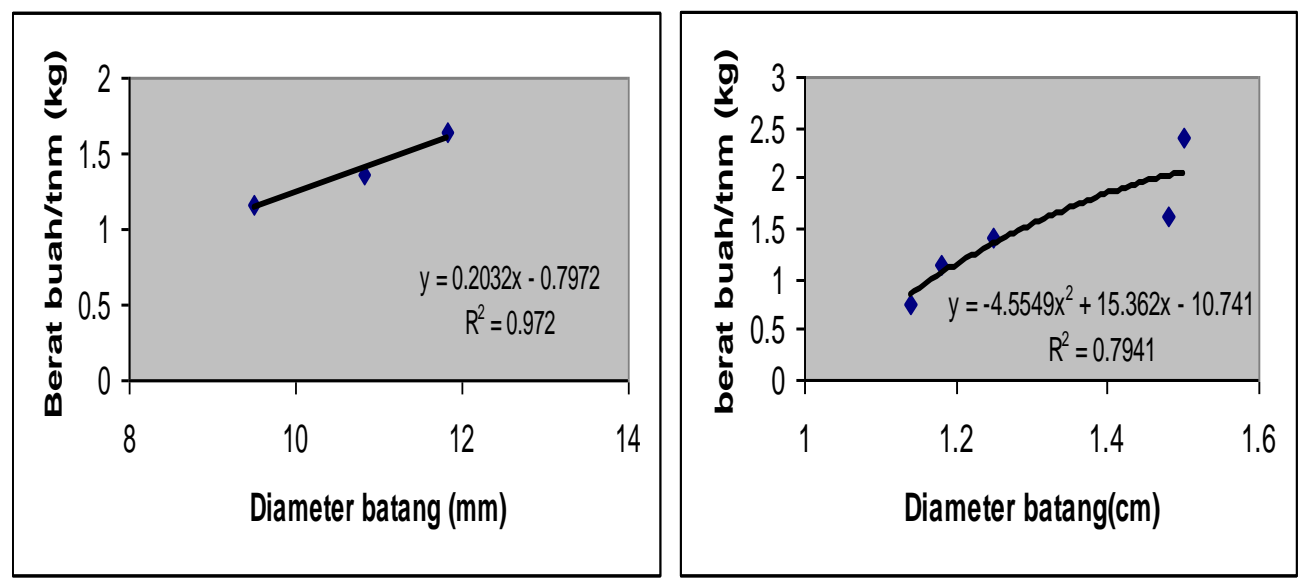

Gambar 9. Kurva hubungan antara Diameter batang tomat dengan berat buah tanaman tomat ( Surip, 2004 )

Gambar 10. Kurva hubungan antara Diameter batang tomat dengan berat buah tanaman tomat ( Surtinah, 2001 ).

\section{SIMPULAN DAN SARAN}

Simpulan yang dapat diambil berdasarkan pembahasan di atas adalah pengukuran tinggi tanaman tomat, Jumlah cabang, dan Diameter batang menunjukkan hubungan yang erat terhadap berat buah tomat per tanaman.

Penelitian tanaman tomat dimasa yang akan datang tetap dianjurkan untuk menyelidiki Tinggi tanaman, Jumlah cabang, dan Diameter batang.

Saran yang dapat diberikan adalah, penelitian sebaiknya diarahkan untuk menyelidiki keeratan hubungan antara parameter pertumbuhan dengan produksi dan sesama parameter pertumbuhan tanaman tomat.

\section{DAFTAR PUSTAKA}

Gomez , K. W. dan Gomez, A. A. 1995.Prosedur Statistik untuk Penelitian Pertanian .edisi kedua. Alih Bahasa oleh Endang Syamsudin, Justika Baharsyah. Penerbit Universitas Indonesia. 698 hal.
Gardner, F. P., R. B. Pearce, dan R. L. Mitchell 1991. Fiologi Tanaman Budidaya. Alih Bahasa Oleh Herawati Susilo dan Subiyanto. Penerbit Universitas Indonesia. 428 hal.

Salisbury, F. B. dan C. W. Ross 1992. Fisiologi Tanaman. Ali Bahasa oleh Diah R. L. dan Sumaryono. Penerbit Institut Pertanian Bogor.

Sariyanto 2004. Pengaruh Pemberian Pupuk Kandang dan Atonik Terhadap Pertumbuhan dan Produksi Tanaman tomat ( Lycopersicum escuentum Mill ). Skripsi. Fakultas Pertanian Universitas Lancang Kuning Pekanbaru. 32 hal.

Susi, N. 2006. Aplikasi Pemberian Beberapa Dosis Pos dan Konsentrasi Liquinox Start terhadap Pertumbuhan dan Produksi Tomat ( Lycopersicum esculentum, Mill ), Jurnal Ilmiah Pertanian, Vol 3. No.1. Hal $17-28$. 
Surip 2004. Pengaruh Pemberian Pupuk Urea dan Gandasil B terhadap Pertumbuhan dan Produksi Tanaman Tomat ( Lycopersicum esculentum Mill ). Skripsi. Fakultas Pertanian Universits Lancang Kuning Pekanbaru. 33 hal.
Surtinah 2001. Pengujian Konsentrasi Gandasil B Terhadap Pertumbuhan dan Produksi Tomat Lycopersicum esculentum Mill ). Fakultas Pertanian Jurusan Budidaya Pertanian Universitas Lancang Kuning Pekanbaru. 32 hal. 